\title{
Transformative Unionism and Innovative Campaigns Challenging Inequality
}

\author{
Michelle Williams, University of the Witwatersrand, South Africa
}

In this article I provide an overview of the articles in this Special Issue of the Global Labour Journal, drawing lessons from the creative and (un)typical campaigns that the authors describe. To begin, the first part of the article gives an overview of inequality, which is then followed by a discussion of the 'mutations in capitalism' over the past forty years. After having set the context, I look at the ways in which labour is responding by drawing on eight interesting and creative campaigns that either directly or indirectly address the causes and consequences of inequality. In the concluding section, I attempt to draw gestural lessons from the cases discussed here.

One of the most persistent and jarring realities of the twenty-first century is the growing inequality within nations. ${ }^{1}$ Since the 1980s the gap between the rich and poor has widened, with the World Bank noting that those at the very top of the global income group have been the major winners of neo-liberal globalisation. Indeed, the 'top $1 \%$ has seen its real income rise by more than 60\% over those two decades [since 1988]' (Milanovic, 2012: 12). Neo-liberal globalisation has mutated capitalism in new and unfamiliar ways, which has intensified and accelerated inequality by dismantling state-supported social welfare systems, industrial and labour market regulations, and state capacity to regulate financial systems, while simultaneously opening economies to fiercely aggressive markets as ever more aspects of life, including nature, become commodified. This has been neither accidental nor consequential. Rather, neo-liberal globalisation is a political project that increases the power of capital at the expense of both states and citizens (Bowles, 2011). However, while it continues to dominate the global economy, its hegemony is waning as people across the globe increasingly register their discontent with the neo-liberal policies that promote further marketisation, resulting in the loss of legitimacy of the neo-liberal project. The loss of legitimacy has also meant that corporations are no longer forced to accommodate the social democratic demands that benefit societal interests, but rather a fiercer pursuit of profits has come to dominate. As a result of this avaricious neo-liberal capitalism, global inequality registers a shocking Gini coefficient of 70 (using the formula of individual incomes) (Milanovic, 2012: 8-9), which highlights the extreme differential conditions of the rich and poor both within and among countries.

Interestingly, while the top $1 \%$ of income earners have been the major winners, the other major winners are the middle income earners of emerging economies such as Brazil, China and India: 'between the $50^{\text {th }}$ and $60^{\text {th }}$ percentile of the global income distribution $\ldots$ we find some 200 million Chinese, 90 million Indians, and about 30 million people each from Indonesia, Brazil and Egypt' (Milanovic, 2012: 12). If the super-rich and middle income earners in emerging economies are the winners, what has happened to the working class and the poor? It used to be that we could reasonably speak about the unemployed poor and the employed working class. Today, however, we speak of the 'working poor' to describe the increasing numbers of people working in unstable and precarious jobs (War on Want, 2009). Thus, the boundaries between unemployed and precariously employed have become blurred, with both living highly fragile lives. By 2007 the number of people unemployed or employed in unstable and insecure jobs was 1485 million, up from 141 million in 1993 (War on Want, 2009: 4). That is, in fourteen years those who work and live in insecure and unstable jobs increased tenfold, to include nearly $20 \%$ of the world's population. For workers and

Global Labour Journal, 2015, 6(3), Page 253 
the poor the reality is increased insecurity and worsening conditions (Bieler and Lindberg, 2011). As Ronaldo Munck explains, the 'mutation of capitalism' has resulted in the 'precaritisation of labour' on a mass scale (Munck, 2013: 248; Standing, 2014). Munck goes on to cogently summarise the class formation that is underway: 'we can now posit the emergence of a new global informal working class which, following Davis, "is about one billion strong, making it the fastest-growing, and most unprecedented, social class on earth" (Davis, 2007: 178, quoted in Munck, 2013: 244). What is especially noteworthy of today's conditions is that there is now a continuum of casualisation and precarity that stretches across the North-South, formal-informal divides. How did this mutation in capitalism come to pass?

\section{Transformation of the Global Economy}

In the post World War 2 period, states came to play an important role in managing economies and ensuring social protection for their citizens, especially in the developed capitalist countries of the global North. It was widely assumed that markets had to be regulated in society's interests, and the relative power of the state vis-à-vis the economy and civil society was formidable. This situation began to break down in the aftermath of the 1973 oil crisis, and the rise of ideological revolutions pushed by Ronald Reagan and Margaret Thatcher hailed market solutions as the answer to economic stagnation and the ostensible inefficiencies of state regulation (Burawoy, 2010). This period saw a new wave of marketisation and ushered in a fundamentally new balance of power in which capital's interests came to dominate. As Walden Bello tells us, capital had three solutions to the stagnation of the 1970s, all of which ultimately increased the power of capital through a renewed market fundamentalism: 1) neo-liberal restructuring; 2) globalisation; and 3) financialisation (Bello, 2013: 5).

Neo-liberal restructuring led states to 1) dismantle state controls 'on the growth, use, and flow of capital and wealth'; 2) destroy the Keynesian class compromise between capital and labour in which labour enjoyed secure and well-paid jobs; and 3) revise tax laws in favour of the rich (Bello, 2013: 5-6). Together these three features of neo-liberal restructuring benefitted the rich as they redistributed income upward from the poor and middle classes. Real incomes of working and middle classes $^{2}$ stagnated and in the 2000s they declined, while the rich became substantially richer. For example, in 2007 in the United States (US) the top 1\% of the population had $30 \%$ of the national income, dramatically up from $10 \%$ in 1957. The ideological justification was that these changes would lead to growth, and it was implied that growth would lead to increased employment. Yet, neoliberal restructuring did not lead to world growth, despite pockets of growth in particular regions. The United Nations (UN) estimates that the 'world GDP grew at an annual rate of 5.4 percent in the 1960s, 4.1 percent in the 1970s, 3 percent in the 1980s, and 2.3 percent in the 1990s' (Bello, 2013: 6). Thus, stagnation persisted even with neo-liberal restructuring.

The second response to stagnation pushed by global capital was globalisation. Globalisation includes both the expansion of the global market economy into nearly all geographical areas of the planet as well as a renewed commodification of labour, money and nature on a transnational scale. Michael Burawoy (2010: 311) explains how a new wave of 'commodification of labour, money and nature - labour migration, finance capital as well as environmental degradation - for the first time takes on a truly transnational character that is often outside the control of the state'. The incentive for capital was new infrastructural investment projects, 'access to cheap labour', and new sources of 'agricultural and raw material products' (Bello, 2013: 7), which was orchestrated through removing barriers to trade, capital mobility and foreign investment. However, as Bello argues, this response by capital only led to further overproduction because 'it added productive capacity', which led to further crises. Ultimately profits and prices declined: 'economist Philip O'Hara, [shows that] the profit rate of the Fortune 500 went from 7.15 in 1960-69 to 5.30 in 1980-90 to 2.29 in 1990-99 to 
1.32 in 2000-02' (Bello, 2013: 7). In addition to the overproduction it generates, globalisation has also turned the natural world into a key site of accumulation, which has left ecological devastation in its wake. By commodifying nature, including water, energy and even the air (through carbon trading), globalisation has threatened our capacity to sustain life. Ultimately globalisation has only exacerbated the crisis.

The third response to stagnation in the real economy was financialisation, in which capital increasingly relied on the credit creation and speculation of the financial sector (rather than the real economy) for its profits. As the purchasing power of the working and middle classes diminished, so too did the demand for goods. In response, the private sector in the global North, especially the US, pushed a massive increase in credit creation by the banks, 'which lowered lending standards and hooked millions of consumers into cheap housing loans, student loans, auto loans, and multiple credit cards' (Bello, 2013: 9). In short, demand was propped up by luring people into debt. Financial speculation was the other way the private sector shored up profits, 'turning [money] from a medium of exchange into a tool of profit making, based on derivatives, futures, securitisation of loans, and operating through hedge funds largely outside the control of states' (Burawoy, 2010: 308). Financialisation led to inherent instability as financial markets are volatile and unstable and do not create any new value.

By the 1990s and 2000s we had continuing crises but weaker states, ineffective labour movements, and the increased power of capital. At the same time, capitalism's negative externalities grew in order of magnitudes with rising inequality, growing numbers living in poverty and going hungry, increasing numbers of people working and living in vulnerable and precarious situations, and ecological devastation. Thus, the last quarter of the twentieth century saw increasing instability in the global economy and greater numbers of people left out of formal economic activity and increasingly living precarious lives.

What have been the responses to these changes in late capitalism? There are two primary categories of responses: responses from above (led by the state and capital) and responses from below (led by popular movements and civil society). One response from above foregrounds the state's role through a renewal of Keynesian attempts to fix the global economy. Very few states and policy makers have actually taken this response seriously enough to give it any real chance of ameliorating the consequences of late capitalism's negative externalities. Another response from above is pushed by capital and its ideological followers through more neo-liberalism in the form of austerity programmes and, in the US, through the war economy. In the main, capital has been able to steer the attempted solutions to the crisis it created and skirt any responsibility for its consequences. Instead, states have failed to regulate and change the dynamics of capitalism and populations are carrying the burden of the 'mutations in capitalism' (Munck, 2013; Bello, 2013).

There have also been responses from below, from civil society including labour movements that invoke people's power and garner the support of ordinary citizens. These range from the 'end of growth' school which argues for the end of a growth-oriented, fossil-fuel-addicted mode of production, to the alternative economies movement that sees local communities exchanging in alternative local currencies. The solidarity economy movement in which alternative forms of production, consumption and finance based on collective ownership and democratic decision making is another response emerging in various places in the world such as Brazil, Argentina, Germany, Italy, Spain and the US. We have also seen a response that argues for deglobalisation, largely associated with Walden Bello in the Philippines. In this Special Issue, we focus on responses in which labour has been an actor in campaigns that directly and indirectly address the consequences of inequality. 


\section{Responses from Labour}

For much of the twentieth century labour movements were at the forefront of most social, political and economic struggles for social transformation. For example, workers and their collective organisations played crucial roles in dismantling authoritarian governments in Latin America (Argentina, Uruguay, Brazil), Southeast Asia (Philippines, South Korea), Europe (Spain, Poland, Greece) and Africa (South Africa) (Valenzuela, 1989; Collier and Mahoney, 1997; Choi, 1993; Seidman, 1994; Scipes, 1996; Von Holdt, 2003). Workers' organisations also secured vital reforms in 'workplace organisation, labour law frameworks and trade union structures, promoting the voice and visibility of working-class actors in key institutional arenas' (Chun and Williams, 2013: 2; Suh, 2009; Webster, 1985). The specific ways in which workers and their organisations have intervened in social struggles has varied across time and place, but they have clearly played an instrumental role in shaping the contours of societies for much of the twentieth century.

However, we must be careful in drawing simplistic path-dependent conclusions about labour's continued role. Indeed, with the mutations in capitalism, labour movements have been systematically weakened and often see themselves on the sidelines of social struggles as they defensively try to hold on to their past gains. Yet, workers and their collective movements still have a role to play, and there are examples where they are engaging in local struggles as well as developing opportunities for forging 'new labour internationalism' (Webster, Lambert and Bezuidenhout, 2008: 210; Stevis and Boswell, 2008; Kay, 2011).

Organised labour has historically played a vital role in humanising production and representing the interests of the working class. The question for this Special Issue, then, is what has been labour's response to increasing inequality? Workers and their organisations are responding to the changes in capitalism and the causes and consequences of inequality in varying ways, some of which pose challenges to capitalism and others of which help ameliorate the pernicious effects of inequality. The scales at which resistance is happening range from the local to the global, and movements often make inter-scalar as well as intra-scalar linkages. The campaigns showcased here also show that movements skip scales, often making links between local and global movements. Without falling into the 'false optimism of global labour studies' (Burawoy, 2010), the articles in this issue provide a complex picture of the role labour has played in mitigating the causes and consequences of inequality at various scales. The experiences demonstrate that in various places labour has forged interesting links with a range of movements, often drawing links between experiences of commodification and exploitation and in the process forming new forms of unionism.

Some of the cases suggest that a potential new form of transformative unionism is emerging, which brings together elements of the economic, political, and social movement unionism of the past, but which extend their practices to untypical labour issues. In the classic rendition, economic unionism refers to trade unions exclusively focusing on their members' demands within the workplace. Political unionism, by contrast, arose as socialist and communist parties sought to harness workers and their organisations for political projects. In the global South, political unionism also linked with nationalist struggles against colonialism and imperialism. In a third variation, social movement unionism brought together trade unions with social movement struggles, taking the struggle beyond the workplace to engage with the broader conditions under which workers live. The iconic case of social movement unionism was in South Africa during the anti-apartheid liberation struggle for political and civil rights in which organised labour formed a formidable alliance with community struggles (Waterman, 1993; Webster, 1988/1994; Seidman, 1994; Pillay, 2013). However, in some places, like South Africa, the alliances with parties in state power have seen the reemergence of political unionism (Pillay, 2013).

Today we see varying combinations of the different forms of unionism, but in some cases workers and their collective organisations are marrying these to untypical practices and issues. It is 
not simply a return to the repertoires of twentieth-century political unionism or social movement unionism that we are seeing. Rather in certain instances a transformative unionism is emerging that maintains autonomy while forming issue-based alliances with social movements, civic organisations and political parties, and engaging the state and corporations. This transformative unionism attempts to challenge both commodification and exploitation, which are simultaneously key features of late capitalism. In the global North, for example, the increase in strike actions against austerity programmes in Europe (especially among Mediterranean countries of Portugal, Spain, France and Greece) clearly demonstrate union responses to the assault on the working class (Nowak and Gallas, 2014). While the strikes are largely defensive and symbolic, they demonstrate the importance of broad alliances across unions and social movements. They also raise important questions about the efficacy of symbolic struggles against increasingly undemocratic states that show little response to widespread societal disgruntlement. While the strikes have received widespread public support, they have largely failed to garner any clear victories. The fact that unions in certain European countries most affected by the Euro-zone crisis have engaged in unprecedented general strike action based on a wide range of alliances with social movements suggests that some unions are attempting to challenge the effects of marketisation that have left their economies in shambles through building broad alliances that go beyond the shop floor.

In looking at the responses of workers and their collective organisations to inequality, it is useful to see the responses lying on a spectrum from highly involved to marginally involved. When we look at their activities on a continuum, it is clear that unions are fighting back, but the degrees to which and the issues around which they fight are rooted in local conditions, particular histories of class formations and political contexts. In the next section, we look at different campaigns that show labour's involvement in fighting the causes or consequences of inequality. There are different types of campaigns challenging inequality: those that directly raise the standards of living of workers and the poor and thus directly address inequality, and campaigns that indirectly address issues of inequality through taking up issues that indirectly improve living and working conditions.

\section{Creative Campaigns to Overcome Inequality}

The articles in this Special Issue look at various creative campaigns to challenge inequality in a number of countries - Brazil, Argentina, Namibia, South Africa and Germany - with varying degrees of involvement by labour movements. The campaigns include the Brazilian labour movement's struggle for gender equality (Luisa da Costa) and its minimum wage campaign (Fred de Melo), Argentina's mass campaign for income redistribution (Luis Campos), South Africa's Treatment Action Campaign (TAC) for access to HIV/AIDS drugs (Mark Heywood) and the National Union of Metalworkers of South Africa's (NUMSA) initiative for climate justice and socially owned renewable energy (Vishwas Satgar), the Namibian Basic Income Grant campaign (Herbert Jauch), Germany's minimum wage and Emmely campaigns (Jörg Nowak), and the European Financial Transaction Tax campaign (Peter Wahl).

In all of these initiatives labour has played a role, often diverging significantly from its traditional activities. Indeed, the campaigns show that labour has been forced to deviate from traditional issues of the shop floor that have preoccupied labour for the greater part of the twentieth century to broaden its range of issues and repertoire of activities. While we have witnessed an increase in general strikes against austerity in Western Europe, many other struggles today look to new and creative tactics that transcend the strike such as pilot projects of creative alternatives, global campaigns that link different nodes in the production cycle, symbolic struggles aimed at winning public support and broad alliances with a wide range of civil society organisations. The campaigns also demonstrate enormous creativity in both the goals and tactics used. It is also interesting that 
labour's role varies across the campaigns from highly involved to marginally involved. The various campaigns teach us the importance of linking the various local struggles with global networks in order to scale up the efforts.

The campaigns on the end of the spectrum with a high level of union involvement include campaigns that directly and indirectly address issues of inequality such as the Climate Justice campaign in South Africa, the Minimum Wage campaigns in Germany and Brazil, the struggle for redistribution in Argentina, and the struggle for gender equality in Brazil. While unions are leading all of these campaigns, they are doing so by building links with a broader base of support and through both typical and untypical campaigns.

One of the most innovative and challenging campaigns led by a trade union is NUMSA's campaign for climate justice. Vishwas Satgar's article shows us how the metalworkers shifted their understandings of development to a radical climate justice perspective that includes economic and energy democracy, energy equality and protection of the natural world. Steeped in the manufacturing sector, it is quite extraordinary that NUMSA has taken the initiative to pursue a campaign that moves beyond fossil-fuel, environmentally destructive manufacturing in favour of such things as a 'socially-owned renewable energy' sector. The climate justice campaign works on several different fronts: 'It seeks to ensure the needs of workers and communities are met while attempting to address the challenges of climate change' and started with a seminar to deepen the union's understanding about climate issues and the implications for their sector, and to initiate the process of developing the union's position. The approach is eclectic and includes 'contesting electricity price increases, seeking to influence the procurement and rollout of solar water heaters and advancing an agenda to achieve socially owned renewable energy options'. To get the members up to speed with the heady and complex world of climate justice, the union had a three-year programme of education, research and development groups, workshops, study tours, international visitors and conferences. As a demonstration of how seriously it takes these issues, the union retrofitted its offices in Johannesburg, Pretoria and Durban to be 'green' buildings with solar power, water harvesting, insulation and so on. Out of these myriad activities, at its 2012 national congress NUMSA adopted two important resolutions - Climate Change and Class Struggle and Building a Socially Owned Renewable Energy Sector in South Africa - which help guide the union as it develops and engages the policy arena. Vital for NUMSA's campaign has been the (re)education of workers and an intensive programme of internal capacity building around cutting-edge green ideas. Thus, the union is invoking a wide range of practices in pursuing its untypical labour campaign for climate justice.

Shifting from the untypical campaign by the metalworkers union in South Africa, the more traditional issue of a minimum wage was a crucial campaign led by labour in Brazil and Germany. As Fred de Melo (Brazil) and Jörg Nowak (Germany) show, the Brazilian and German campaigns for a minimum wage directly address issues of inequality by forcing the state to pass minimum wage legislation that protects workers at the bottom of the wage hierarchy. In both cases the campaign was led by the main labour federations, the Central Única dos Trabalhadores (CUT, Unified Workers Central) in Brazil and the Deutscher Gewerkschaftsbund (DGB, German Coalition of Trade Unions) in Germany. Both federations fought not only to pass legislation ensuring a minimum wage but also to raise the floor of the minimum wage. Melo shows how the minimum wage in Brazil not only sets the wages for workers at the bottom, but it also 'determines the floor for pension, welfare and unemployment insurance benefits'. Thus it has a central role in policy making within Brazil and, together with other programmes such as Bolsa Familia, the minimum wage campaign directly challenges inequality as over thirty million people received an income corresponding to the minimum wage as of 2012. In both countries the campaigns were waged through organising mass demonstrations and marches, raising public awareness, and engaging with policy makers and political parties. In both places, the campaigns enjoyed widespread support from the public. As a result the 
Brazilian minimum wage value rose 68\% since the first march in 2004 and is set to incrementally increase through 2023. In Germany, however, Nowak explains that the minimum wage legislation was only passed by the German Parliament in July 2014. The campaign has a much more modest goal in terms of incremental increases, but secured universal minimum wage agreements that began in January 2015. What is particularly noteworthy about the German minimum wage campaign is that it demonstrates trade unions' capacity to shape public discourse in order to win support for the idea of a minimum wage, even for those who are not members of unions. In Brazil the battle was assisted by the progressive political environment created by the Workers Party coming to power, the moral mandate from the public, and constitutional provision that ensures people have access to basic conditions of life. In Germany, on the other hand, the dynamics of electoral competition opened up space for the DGB to forge alliances with left political parties to push through the minimum wage. The range of activities used is also noteworthy as information campaigns, protests, research, lobbying and collective bargaining were enlisted in the campaign. Thus, the minimum wage campaigns in both Brazil and Germany demonstrate the efficacy of creative union organising that invokes widespread public support to pressurise left political parties.

Shifting from the traditional labour federations, the Argentine movement for income redistribution is an innovative campaign that brought the issue of inequality into the homes of the general public. Luis Campos shows how the National Front Against Poverty (FRENAPO) was a creative, non-partisan and broad movement to push government to adopt progressive measures that would eliminate poverty. It was the first of its kind in Argentina. The struggle to eradicate poverty came in the context of growing unemployment and increased insecurity for large numbers of Argentines. The campaign was led by a broad coalition of forces, including the Argentinean Workers' Union (CTA), the unemployed movement, peasants, indigenous groups and human rights groups. While the CTA was the main driver, the campaign was framed as a human rights issue rather than a labour issue, which helped it gain widespread support. Over three million people supported the campaign, and the climax of the campaign was to present government the results of the referendum in support of the campaign. However, this could not be done due to the economic crash in December 2001 and the subsequent fall of the government. (Argentina had five presidents between 20 December 2001 and 5 January 2002.) The events of history overtook the campaign. Nevertheless, the campaign managed to penetrate public opinion, and the centre-left government that has been in power since 2003 has taken up a number of the issues of the campaign and has pursued various social policies that fall within the campaign guidelines. The CTA's role was instrumental as the largest partner in the coalition, but it did not control or lead the process. As an autonomous and independent union, the CTA has a history of taking up issues beyond the shop floor, such as public services and housing, and it has been organising informal-sector workers for over a decade. One of the most creative aspects of the campaign was the way in which it framed the issue of eradicating poverty in terms of citizenship and rights, which resonated with the general public. In the process it was creating symbolic power by winning public support for its demands. The FRENAPO experience demonstrates the synergistic relations that unions can forge with a broad range of organisations in civil society for a common purpose.

Luisa da Costa shifts our attention to the Brazilian struggle for gender equality led by the National Secretary of the Women Workers of CUT (SNMT/CUT), which had an innovative campaign for 'equality of opportunities in life, in work and in the labour movement.' The SNMT has been vital in mainstreaming gender within the CUT and has influenced a number of its positions, such as quotas, through its original campaign in 1988. In 2008 CUT decided to re-launch the campaign because women's positions in society, work and the home continue to be characterised by extreme forms of inequality, marginalisation and discrimination. The campaign calls for equality in life, in the workplace and in the labour movement. It has a series of initiatives in each category, and

Global Labour Journal, 2015, 6(3), Page 259 
uses methods such as information sharing, policy interventions, seminars and educational workshops. By focusing on women's issues, the campaign indirectly addresses inequality in society as women bear the greatest burden of social reproduction and are most affected by poverty and inequality.

All of these campaigns have seen labour movements play a central role in pioneering creative campaigns that challenge inequality. In the cases that follow - access to HIV/AIDS drugs in South Africa, the Basic Income Grant in Namibia, and the Emmely campaign in Germany - we move down the spectrum to campaigns in which labour has been involved but has not led the struggles. Again, these struggles both directly and indirectly challenge inequality in society.

Mark Heywood takes us along on the journey of accessing anti-retroviral drugs in South Africa. Looking at the TAC's struggle for universal access to anti-retroviral drugs reveals that the campaign was fundamentally about issues of inequality, and part of its success was due to gaining the support of the main labour federation, the Congress of South African Trade Unions (COSATU). The class basis of HIV/AIDS in South Africa mirrored apartheid cleavages: the overwhelming majority of those infected and affected are the working class and the poor, and especially women. The struggle, therefore, importantly affected those who could not afford the expensive drug cocktail. Thus, the TAC's struggle was not only about access to life-saving drugs, but also a struggle to overcome class-based inequalities in accessing these drugs. The innovative strategies and tactics that the campaign used introduced new forms of struggle into South African protest politics, which tends to rely heavily on confrontational politics. The TAC used symbolic protests in which moral and legal (and constitutional) legitimacy were the underpinning sources of power. The innovative way in which the TAC reclassified struggles for access to anti-retroviral drugs centred on human rights and enlisted support from both national and international actors. The reframing of the issues transformed the struggle from a special-interest struggle into a struggle for basic rights. The methods used included highly visible campaigns, public media to deepen public awareness and understanding, provocative 'T-shirt slogans (e.g. 'HIV POSITIVE'), court cases using the progressive legal framework, and charging public leaders with culpable homicide, which helped frame the struggle as just and drew on symbolic power. The moral legitimacy of the rights framework and the pro-poor laws that exist meant that litigation became a powerful tool to build power from below. The alliance forged with COSATU was crucial to the TAC's success as the federation was able to directly mobilise over two million people and exert pressure on the Presidency. The TAC's struggle demonstrates how citizens (many of whom were members of unions) became actively engaged in creative struggles against both the state and transnational pharmaceutical corporations, and in the process challenged the unequal access to life-saving drugs and deepened democratic activism.

Moving from the world of health as a universal right, Herbert Jauch shows us how the Namibian Basic Income Grant (BIG) initiative was an attempt to pioneer a universal grant system that would help alleviate dire conditions of the poor. Facing heavy resistance from international bodies such as the International Monetary Fund (IMF), the initiative ran a pilot project to demonstrate that the BIG could be administered and that it would have positive developmental impacts and reduce inequality. The developmental impacts of the pilot surpassed the expectations of those involved in the project. It not only alleviated dire conditions of poverty, but it also had the unintended consequences of reducing domestic violence, empowering women and increasing the school attendance rate of children. The initiative was designed to converge with participatory democratic processes by requiring communities to collectively discuss and manage the campaign. A committee was elected from the community to oversee the implementation, which rooted it within the local community and helped to ensure transparency. There were a number of crucial organisations that supported the BIG such as churches, trade unions (the main Namibian federation was actively involved), NGOs, AIDS organisations, legal aid, labour research organisations and, 
surprisingly, the business community and some international agencies. While the initiative was not expanded to the national level due to complex internal political wrangling, the initiative nevertheless demonstrated the positive correlation between providing a universal basic income, decreasing poverty and inequality, and revitalising democracy. Labour's support for the campaign was vital, if limited, and also demonstrates its willingness to forge links with a range of organisations, explore new types of programmes that do not directly affect its members and engage in pilot projects. On all these fronts, the Namibian federation was charting new paths of labour activism that addressed issues of (de)commodification.

Going from universal income to a particular case of a woman unjustly fired from her job, Jörg Nowak explains that the Emmely campaign in Germany also directly attempted to challenge differential treatment of workers and managers, thus combating inequality. However, the campaign only received marginal union support. It was a bottom-up campaign in defence of a shop clerk who lost her job for ostensibly stealing two coupons worth 1,30 Euro. Two things that are noteworthy in this campaign is that the struggle was largely waged outside of formal union structures and primarily invoked symbolic protests, which centred around the unjust world in which bankers get away with 'stealing' billions of Euros while a shop clerk is fired after 32 years of service for allegedly taking two Euros. The campaign demonstrates the power of symbolic struggles aimed at winning public opinion and the way in which the legal system can be a weapon of struggle for greater equality. Interestingly, in Germany we have two cases - minimum wage and Emmely - of an institutionalised trade union movement and grassroots movements engaging in struggles to directly challenge inequality, but with varying union support.

While labour movements were not at the helm of these struggles, their support and involvement was vital to the campaigns and, conversely, helped push the unions out of their traditional comfort zones to pursue untypical campaigns. There is one campaign - the European Financial Transaction Tax (FTT) - that both directly and indirectly challenges inequality, and in which labour's role is low on the spectrum of labour movement involvement.

In a Global Issues article, Peter Wahl explains that the European Financial Transaction Tax campaign directly challenges inequality on a very macro level, and became the flagship demand of the 'global justice movement'. While finance and taxation are leading causes of inequality, some labour movements (e.g. the AFL-CIO) supported the campaign but were not integrally involved. For the past fifteen years civil society in different European countries (most notably France and Germany) have pushed for the FT'T and have slowly influenced some government leaders in a 'coalition of the willing'. The 2008 economic crisis shifted the balance of power in favour of supporters of the tax, with public opinion shifting strongly in support. As a result, the EU Commission's draft directive aligned in important ways with civil society's proposals. While civil society has been bolstered in recent years, the finance industry remains strongly opposed and continues to have substantial influence over policy makers and political leaders. One of the most notable features of the campaign is that it successfully tapped into the Zeitgeist in terms of the general frustration with neo-liberal economic policies. In addition, the campaign was able to galvanise civil society to engage in grassroots activities that eventually won popular support for the tax and also pressured elites to be more responsive to reforms. Another notable feature is the low level of labour movement involvement in the campaign, despite its central role in challenging big finance capital. As Wahl demonstrates, labour has only been marginally supportive of the struggles for the financial transaction tax in Europe, but he suggests that it has a vital role to play.

Taken together, this wide range of experiences shows that workers and their collective organisations are to varying degrees engaging in creative and innovative campaigns that challenge inequality in society. The cases also demonstrate the importance of building on old forms of power (e.g., strike, collective bargaining, negotiation, internal capacity) with new forms of power (e.g., 
symbolic, public support, pilot projects).

\section{Gestural Lessons}

With the mutations in capitalism since the 1970s, workers' power in the labour market and their share in the social surplus have diminished (Bieler, Lindberg and Pillay, 2008). While scholars see two possible responses in terms of labour organising (Pillay, 2013) - return to social movement unionism (Clawson, 2008), and increasing defensive struggles and political incorporation (Fairbrother and Webster, 2008; Schiavone, 2007) - we also see an interesting shift in social movements that are looking to draw labour into popular struggles outside the workplace in order to strengthen their appeal to symbolic power. Here it is not the traditional union leverage at the point of production that is being looked to, but rather unions are seen as a vital source of power as they can lend legitimacy to claims of moral and legal rights (Chun, 2009). For example, COSATU's support for the TAC legitimated the claims for medication as a right affecting all people and not simply a medical issue for a relatively small group of affected people. Similarly, the union federation's support for the BIG in Namibia lent the campaign legitimacy in the public sphere. Interestingly, the cases demonstrate the importance of not only pursuing typical labour campaigns, but also untypical issues such as health, universal basic income, taxation and climate change. In fact, some of the most creative campaigns are in untypical issues that force labour to pursue broader alliances and new tactics (e.g., energy studies, shaming rituals, provocative 'HIV POSITIVE' Tshirts).

One of the most significant lessons from the cases in this Special Issue speaks directly to the nature and character of trade union alliances with political parties and the state. The political unionism of the twentieth century saw trade unions emerge as arms of political parties, often subordinated to the political mandates of the party, which contrasts to the social movement unionism of the 1980s in which unions looked to society and popular struggles for their alliances (Pillay, 2013). While these distinctions are still relevant to understanding the character and orientation of many unions, a number of the cases in this Special Issue are attempting to find a transformative unionism that draws on elements of both political and social movement unionism. A number of articles suggest that unions are often in a stronger position by keeping their autonomy from political parties, but maintaining open relations to support progressive policies championed by parties as well as maintaining the capacity to contest regressive and anti-social state policies. It is clear that states have a vital role to play in championing social transformation, but that they often lack political will to play this transformative role. Thus, states are often unwilling to pass peoplefriendly (and worker-friendly) laws and policies, regulate capital and steer the economy in redistributive directions. It is therefore crucial for labour movements to have the capacity to challenge the state. This is most vividly demonstrated in minimum wage campaigns in Brazil and Germany. It is important to note that these transformative actions are political, but not aligned (or subordinated) to a single party.

While the articles suggest caution when it comes to forming close alliances with political parties and the state, all of the articles highlight the importance of forging broad alliances with a range of organisations in civil society in order to keep pressure on the state. For example, the Financial Transaction Tax campaign in Europe has sought broad alliances with civil society including organised labour - and with political parties and individual members of parliament. Similarly, the articles on the Basic Income Grant in Namibia and the labour struggles in Germany demonstrate the efficacy and importance of broad social alliances. The benefits emanating from such alliances include sharing resources and ideas, and the increase in public support that is crucial for policy change as shown in the impact of public pressure in the Emmely struggle in Germany.

Global Labour Journal, 2015, 6(3), Page 262 
Another important lesson from the campaigns showcased here is the need to work at various scales - local, national, regional and global - and the ways in which they can link up in creative and interesting ways (McBride and Smith, 2013; McCallum, 2013). For example, the Financial Transaction Tax joined national struggles into a regional campaign, while the local struggle of Emmely in Germany was scaled up into a national campaign raising the issue of inequality and an outdated anti-labour legal framework.

Existing institutional, legal and policy spaces have often been ignored or underacknowledged as areas of struggle, but are increasingly recognised as important avenues of struggle. The TAC in South Africa and the minimum wage campaign in Brazil teach us that there are often important spaces within the existing legislative and constitutional framework within a country. It behoves movements to explore these avenues in order to exploit latent opportunities within the existing institutional, legal and policy apparatuses. In addition to finding openings in the current legal framework, the articles also highlight the importance of maintaining mobilisation as the legal arena cannot replace the importance of popular mobilisation.

Linked to challenging the legal system is the importance of alternative expertise and knowledge production in the form of reports and documents that contest the 'truths' espoused by corporations and 'experts'. The importance of this is demonstrated in the two South African campaigns (Treatment Action Campaign and NUMSA's climate justice campaign), the Financial Transaction Tax campaign in Europe, and the income redistribution campaign in Argentina. The campaigns put alternative information in the public realm, challenging the dominant views on health, climate justice, taxation, and income inequality and redistribution. In all these campaigns the alternative narratives were a vital part of the struggle to win public support and symbolic leverage. Focusing on pilot projects and alternatives also shifts practices from only protesting against something (which often means maintaining the highly iniquitous status quo) to envisioning transformative alternatives in practice. NUMSA's energy workshops and socially-owned renewable energy programme provide alternative scenarios around which labour can mobilise. Thus, in creating alternative understandings (through building alternative 'expertise'), the struggles also propose alternative scenarios for the ways things can be done.

In conclusion, the campaigns range from typical to untypical issues, direct and indirect ways of overcoming inequality, with some led by trade unions and others led by social movements with trade unions as one partner in the process. In all the cases, the state and/or capital are the targets of the transformative politics, and varied approaches to the state and political parties are represented. The range of campaign issues and the varied trade union involvement have much to teach us about the role of labour in overcoming inequality today.

\section{NOTES}

${ }^{1}$ The global income inequality among nations has registered a small decline over the past decade in large part due to the growing middle classes in emerging economies, especially China and India, as well as the declining income of the middle class in the United States and Europe. However, the actual decline in global inequality is illusory as the incomes of the top $1 \%$ are often underestimated and the data does not include global tax havens (Milanovic, 2014).

2 The income of the middle class in the global North stagnated, while the emerging economies' middle classes saw their incomes rise in this period. For a fuller discussion of this, see Milanovic (2012, 2014). 


\section{REFERENCES}

Bello, Walden (2013) Capitalism's Last Stand? Deglobalisation in the Age of Austerity. London and New York: Zed Books.

Bieler, Andreas and Ingemar Lindberg (2011) Globalisation and the New Challenges for Transnational Solidarity: An Introduction. In Global Restructuring, Labour, and the Challenges for Transnational Solidarity, edited by Andreas Bieler and Ingemar Lindberg. London: Routledge.

Bieler, Andreas, Ingemar Lindberg and Devan Pillay (eds) (2008) Labour and the Challenges of Globalisation: What Prospects for Transnational Solidarity? London: Pluto.

Bowles, Paul (2011) Globalisation's Problematic for Labour: Three Paradigms. Global Labour Journal, 1(1): 12-31.

Burawoy, Michael (2010) From Polanyi to Pollyanna: The False Optimism of Global Labour Studies. Global Labour Journal, 1(2): 301-13.

Choi, Jang Jip (1993) Political Cleavages in South Korea. In State and Society in Contemporary Korea, edited by Hagen Koo. Ithaca and London: Cornell University Press.

Chun, Jennifer Jihye (2009) Organising at the Margins: The Symbolic Politics of Labour in South Korea and the United States. Ithaca: ILR Press.

Chun, Jennifer Jihye and Michelle Williams (2013) Labour as a Democratising Force? Lessons from South Africa and Beyond. In Rethinking Development and Inequality, 2 (April): 1-9.

Clawson, Dan (2008) Neo-liberalism Guarantees Social Movement Unionism. Employee Responsibilities and Rights Journal, 20: 207-12.

Collier, Ruth Berins and James Mahoney (1997) Adding Collective Actors to Collective Outcomes: Labour and Recent Democratisation in South America and Southern Europe. Comparative Politics, 29(3): 285-303.

Fairbrother, Peter and Edward Webster (2008) Social Movement Unionism: Questions and Possibilities. Employee Responsibilities and Rights Journal, 20: 309-13.

Kay, Tamara (2011) NAFTA and the Politics of Labour Transnationalism. New York: Cambridge University Press.

McBride, Stephen and Scott Smith (2013) In the Shadow of Crisis: Economic Orthodoxy and the Response of Global Labour. Global Labour Journal, 4(3): 206-29.

McCullam, Jamie (2013) Global Unions, Local Power: The New Spirit of Transnational Labour Organising. Ithaca: ILR Press.

Milanovic, Branko (2012) Global Income Inequality by the Numbers: History and Now. World Bank policy research working http:/ / elibrary.worldbank.org/doi/pdf/10.1596/1813-9450-6259.

Milanovic, Branko (2014) National Vices, Global Virtues: Is the World becoming more Equal? Global Inequality, December $22 . \quad$ Available online at http:/ /glineq.blogspot.co.uk/2014/12/ national-vices-global-virtue-is-world.html?spref=tw.

Munck, Ronaldo (2013) Global Crisis: Global Opportunity? Trade Unions, Migration and Social Transformation. Global Labour Journal, 4(3): 236-51.

Nowak, Jörg and Alexander Gallas (2014) Mass Strikes Against Austerity in Western Europe - A Strategic Assessment. Global Labour Journal, 5(3): 306-21. 
Pillay, Devan (2013) Between Social Movement and Political Unionism: COSATU and Democratic Politics in South Africa. Rethinking Development and Inequality, 2 (April): 10-27.

Schiavone, M. (2007) Moody's Account of Social Movement Unionism: An Analysis. Critical Sociology, 33: 279-309.

Scipes, Kim (1996) KMU: Building Genuine Trade Unionism in the Philippines, 1980-1994. Quezon City: New Day.

Seidman, Gay (1994) Manufacturing Militance: Workers' Movements in Brazil and South Africa, 1970-1985. Berkeley: University of California Press.

Standing, Guy (2014 [2011]) The Precariat: The New Dangerous Class. London: Bloomsbury Academic Press.

Stevis, Dimitris and Terry Boswell (2008) Globalisation and Labour: Democratising Global Governance. Lanham, MD: Rowman \& Littlefield.

Suh, Doowon (2009) Political Protest and Labour Solidarity in Korea: White-collar Labour Movements after Democratisation (1987-1995). London and New York: Routledge.

Valenzuela, Samuel (1989) Labour Movements in Transitions to Democracy: A Framework for Analysis. Comparative Politics, 21(4): 445-72.

Von Holdt, Karl (2002) Social Movement Unionism: The Case of South Africa. Work, Employment and Society, 16(2): 283-304.

Von Holdt, Karl (2003) Transition from Below: Forging Trade Unionism and Workplace Change in South Africa. Pietermaritzburg: University of KwaZulu-Natal Press.

War on Want (2009) Trading Away Our Jobs: How Free Trade Threatens Employment around the World. Available online at http://www.waronwant.org/attachments/trading $\% \quad 20$ Away $\% 20$ Our $\%$ 20Jobs.pdf.

Waterman, Peter (1993) Social Movement Unionism: A New Union Model for a New World Order? Review, 16(3): 245-78.

Waterman, Peter (2004) Adventures of Emancipatory Labour Strategy as the New Global Movement Challenges International Unionism. Journal of World Systems Research, 10(1): 217-53.

Waterman, Peter (2008) Social Movement Unionism in Question: Contribution to a Symposium. Employee Responsibilities and Rights Journal, 20: 303-8.

Webster, Edward (1985) Cast in a Racial Mould: Labour Process and Trade Unions in the Foundries. Johannesburg: Ravan.

Webster, Edward (1988/1994). The Rise of Social Movement Unionism: The Two Faces of Black Trade Union Movements in South Africa. In Work and Industrialisation in South Africa, edited by E. Webster, L. Alfred, L Bethlehem, A. Joffe and T-A. Selikow. Johannnesburg: Ravan. [Originally published in 1988 in State, Resistance and Change in South Africa, edited by P. Frankel, N. Pines and M. Swilling. London: Croom Helm].

Webster, Edward, Robert Lambert and Andries Bezuidenhout (2008) Grounding Globalisation: Labour in the Age of Insecurity. Malden, MA: Blackwell. 


\section{BIOGRAPHICAL NOTE}

MICHELLE WILLIAMS is Associate Professor of Sociology at the University of the Witwatersrand (Wits) in Johannesburg, South Africa. She was the Ela Bhatt Visiting Professor at Kassel University, Germany, in 2014. Her book, The Roots of Participatory Democracy: Democratic Communists in South Africa and Kerala, India (Palgrave, 2008), compares the political projects of the communist parties in South Africa and Kerala during the 1990s. She edited South Africa and India: Shaping the Global South (with Isabel Hofmeyr, Wits University Press, 2011), Labour in the Global South: Challenges and Alternatives for Workers (with Sarah Mosoetsa, ILO Press, 2012), Marxisms in the 21st Century: Crisis, Critique, and Struggle (with Vishwas Satgar, Wits University Press, 2013), and The End of the Developmental State? (Routledge, 2014). She is currently working on a book project with Vishwas Satgar on the solidarity economy, focusing on cooperatives in the global political economy, and tracing the linkages from consumer markets to producer cooperatives. [Email: Michelle.Williams@wits.ac.za] 